\title{
Auditor's Characteristics and Earnings Management in India
}

\author{
Hanish Rajpal ${ }^{1} \&$ Pawan Jain $^{1}$ \\ ${ }^{1}$ Institute of Management Technology, Nagpur, India. \\ Correspondence: Institute of Management Technology, 603, Khullar Apartments, Byramji Town, Nagpur -440013. \\ Maharashtra, India
}

Received: September 5, 2017

Accepted: August 24, 2018

Online Published: September 7, 2018

doi:10.5430/afr.v7n4p43

URL: https://doi.org/10.5430/afr.v7n4p43

\begin{abstract}
This study investigates whether auditor's characteristics such as its independence and professional quality act as a deterrent to earnings management in India. The existing evidence on the relationship of auditor's independence and quality with earnings management is not conclusive. The said relationship has not been examined in the context of Indian companies. The study uses a panel data of 1,600 firm years. The study provides evidence on the presence of knowledge spillover hypothesis as negative relationship is found between fees for non-audit services and earnings management. The study does not find any significant relationship of earnings management with industry specialization of the auditor and size of the auditor. The results are consistent under various robustness checks.
\end{abstract}

Keywords: earnings management, auditor, non-audit fees, big 4, panel data

\section{Introduction}

Earnings management (EM) may be defined as the practice of altering the earnings, by using management discretion or judgment and flexibility provided by accounting principles, in order to achieve a desired objective. It has been argued that EM reduces the quality and information content of earnings (Wang et al., 1993; Ali and Pope, 1995). Prior literature has also argued that reported earnings are related to stock returns (Das and Lev, 1994; Liu and Thomas, 2000).

Considering that the opportunistic behavior of managers impacts the quality of financial reporting and thereby the decision making process of stakeholders, accounting earnings will be more reliable if the opportunistic behavior of the managers is controlled (Dechow et al., 1996). Fama and Jensen (1983) and Williamson (1988) argue that measures of corporate governance can constrain the covetous behavior of management. This study focuses on the effectiveness of auditor, an external mechanism of corporate governance, in constraining the practices of EM.

The audit of financial statement is a form of external governance where an 'independent' auditor audits the internal controls and financial statement of the firm, and presents his opinion to the owners of the company. The threat that any misstatement in the financial statement will be reported by the auditor to the shareholder works as the governing measure for the management of the firm. Therefore it is expected that an external audit will act as a deterrent for the management to manage the earnings. The deterrent of external audit, however, is dependent on two major characteristics of auditor viz. the independence and the professional quality. The objective of this study is to investigate the effect of such characteristics of the auditor on EM in India.

We measure EM using aggregate accrual model, specifically performance matched discretionary accrual model proposed by Kothari et al. (2005) is used. This model has been extensively used in prior research related to EM. For auditor's characteristics, three variables have been identified from the previous literature viz. non-audit fees paid to auditor (NAF), industry specialization of the auditor (INDSAUD), and size of the auditor (BIG4). The study tests the effect of these three variables on EM using a panel data of 1,600 firm years selected by stratified random sampling. A battery of robustness tests is also conducted in order to establish the efficacy of the results.

The study finds a negative relationship between NAF and EM. The results points towards the knowledge spillover effect from non-audit services provided by the auditor to its auditing function. The study does not find any significant relationship of EM with INDSAUD or BIG4.

\section{Literature Review and Hypotheses Development}

Auditor independence is critical to the audit quality as any impairment in the auditor's independence may lead to biased opinion in the financial statement. Tepalagul and Lin (2015) argue that if auditors do not remain independent 
they will be less likely to report irregularities, thereby impairing audit quality. The Guidance note issued by the Institute of Chartered Accountant of India (ICAI) discusses the potential threats to auditor independence. One of the threats is a self-interest threat that there is an undue dependence on client's fees. In this regard it is important to note that the economic dependence on client may increase if the auditor provides non-audit services such as taxation consultancy or consultancy for company law related matters, to the client (Becker et al., 1998).

Prior research, however, also provides factors that counter the above argument. These factors include reputation concerns (DeFond et al., 2002), litigation threat (Palmrose, 1988) and knowledge spillover (Simunic, 1984). Simunic (1984) argues that providing both auditing as well as management advisory services may give the auditor better understanding of the business model, risk associated etc. of the client and therefore will help in performing the audit function more effectively. Palmrose (1986) also investigate the effect of non-audit services on pricing of audit services and found a positive relationship between the two, similar to Simunic (1984). However, in the context of Australian companies, Barkess and Simnett (1994) fails to find any significant relationship between fees for non-audit services and audit opinion decision. Dechow et al. (1996) argue that the probability of earnings manipulation being detected and excluded from financial statements depends of the independence and quality of auditor. DeFond et al. (2002) find no evidence of a significant association between auditor's propensity to issue a going concern opinion and NAF. On the other hand, Beeler and Hunton (2002) find that there is more biasedness in decision making of audit partners when the audit firm provides non-audit services. Lim and Tan (2008) demonstrate that for industry specialized auditors the audit quality increases with the level of non-audit services provided.

Gore et al. (2001) argue that non-audit services impact the independence of auditors leading to lower quality of financial reporting. Their study provides evidence that non-audit services are positively related to discretionary accruals (DA). However, such relationship is stronger in case on non-big five auditors. Frankel et al. (2002) demonstrate that firms purchasing more non-audit services are more likely to just meet analyst expectations and have higher absolute DA.

Chung and Kallapur (2003) do not find that NAF is significantly related to abnormal accruals. Their findings are contradictory to the findings of Gore et al. (2001) and Frankel et al. (2002). Ashbaugh et al. (2003) also find no significant association between NAF and performance matched DA.

Larcker and Richardson (2004) they find that the ratio of total fee to total revenue and NAF to total revenue are negatively associated with absolute DA, signifying that firms making larger payments to the auditors have smaller accruals. Antle et al. (2006) find that the knowledge spillover hypothesis prevail between audit services and non-audit services as the level of abnormal accruals reduces with increase in non-audit services. Gerayli et al. (2011) find that log of audit fee is negatively related to EM suggesting that higher auditor fee leads to lower level of DA. Krishnan and Visvanathan (2011) argue that cost savings and knowledge spillover are the main benefits where the auditor also provides other services such as services on tax matters. Their findings suggest that the due to knowledge spillover, when the auditor provides tax services the level of earnings management reduces as the auditor is better acquainted with the firm's operations.

In the context of New Zealand, Sharma et al. (2011) demonstrates that a NAF is positively associated with EM. The study also demonstrates that the positive association becomes more pronounced when the audit committee does not meet the best practices. Ghosh (2011) find that firms having high DA are less likely to be audited by domestic auditors. Secondly, audit fee is higher for firms with high earnings opacity. Lisic (2014) finds that where the tax services provided by the auditor are approved by an effective audit committee, knowledge spillover hypothesis is prominent. Abdullahi and Ibrahim (2017) find no impact of auditor independence on EM.

In India, the Companies Act, 2013 prohibits certain services, including accounting and book keeping, internal audit, design and implementation of financial information system etc., to be provided by the auditors. There was no such provision in the erstwhile Companies Act, 1956.

The above discussion of literature provides contradictory arguments and empirical evidence of the effect of non-audit services on audit independence and audit quality, and thereby on EM. In light of this, the following hypothesis is proposed:

\section{H1: There is a significant relationship between fees paid for non-audit services and EM.}

Solomon et al. (1999) argue that industry specialist auditor acquire greater knowledge of that industry than the non-specialist auditors and, therefore, they are able perform their audit function more effectively than others. Prior studies have also shown that industry specialized auditors have higher capabilities to reveal accounting irregularities (Owhoso et. al., 2001). Carcello and Nagy (2004) find a that firms audited by industry specialized auditor have lower 
probability for an SEC enforcement action. Balsam et al. (2003) investigates the association between earnings quality and auditor industry specialization. The multivariate test results suggest negative and significant relationship between DA and auditor industry specialization. Krishnan (2003) shows that the firms audited by non-specialist auditors tend to have higher DA.

In the context of Singaporean companies, Rusmin (2010) argues that probability of detecting EM is higher if the firm is audited by a high quality auditor. The results confirms the argument by considering big 4 firm as the proxy for quality of auditor. Chi et al. (2011) find that auditor industry specialization at a city level is associated with higher real EM, particularly for income-increasing EM. National level industry specialization, however, does not have any significant impact. In the context of Iranian companies, Gerayli et al. (2011) find that auditor industry specialization is negatively related to EM. Burnett et al. (2012) find that when the financial reports are audited by high quality auditor, the managers tend to swap the accrual based EM with real EM. Similarly, Inaam et al. (2012) demonstrate that auditor industry specialization negatively effects accrual based EM. Sun and Liu (2013) suggest that the auditor industry specialization complements board independence in the governance process. Huang and Liang (2014) find negative relationship of industry specialized auditor and income increasing DA.

The above discussed literature provides that with auditor industry specialization the level of EM is expected to reduce, although the evidence is missing for Indian companies. Therefore, the study has the following hypothesis:

\section{H2: There is a negative relationship between auditor industry specialization and EM.}

The response to the question whether the size of the auditor (i.e. Big4 versus non-big 4) enhances the audit quality has also remained largely inconclusive. DeAngelo (1981) argues that audit firm size is a proxy for the audit quality as no single client is economically highly significant for a large audit firm. Therefore, large accounting firms are less likely to compromise on the quality of the audit. Dopuch and Simuic (1980) propose the reputation hypothesis for large audit firms. They argue that large audit firms provide better quality of audit as they have higher reputation to protect. They further argue that large firms can afford better trainings and resources that may enhance the audit quality. Contrary to this view, Louis (2005) argues that small or non-big4 auditors have better understanding of the local markets and therefore they are able to better detect financial irregularities than big 4 auditors.

Gore et al (2001) find that big five auditors are more effective in constraining EM than non-big five auditors. However, Frankel et al. (2002) and Davidson et al. (2005) do not find any significant relationship between the size of the auditor and absolute DA or EM. Jordan et al. (2010) investigates whether the auditor size, assuming it a proxy for auditor quality, reduces EM related to EPS rounding-off tendency. They find that the tendency of income increasing EM is significant for clients of non-big 4 auditors. In Chinese context, Chen et al. (2011) demonstrate that absolute DA for firms audited by top 8 auditors is significantly lower than of the firms audited by other auditors. Chi et al. (2011) find that for companies that have income-increasing EM, auditor size is significantly associated with higher real EM. Huang and Hsiao (2011), for a sample from U.S. based SMEs, prove that SMEs engage in income increasing EM when they face zero or negative earnings. The empirical results of their study also suggest that SMEs that indulge in EM tend to appoint low quality auditors. Gerayli et al. (2011) find that there is a significant negative impact of auditor size on EM. Haw et al. (2011) hypothesize that misclassification decreases if the company is audited by a big 4 auditor. Their results, however, fail to demonstrate any significant reduction in misclassification when the firm is audited by a big 4 auditor as compared to when the firm is audited by non-big4 auditor, perhaps due to weak legal enforcement in East Asian countries. Inaam et al. (2012) find that when the company is audited by a Big 4 auditor, the accrual based EM reduces and the real EM increases. Memis and Cetenak (2012) demonstrate no significant relationship in the sample of eight countries. While investigating the effect of various corporate governance attributes on EM for French companies, Ajina et al. (2013) do not find a significant relationship between size of the auditor and EM. In Tunisian context, Charfeddine et al. (2013) report an insignificant relationship between EM and auditor size. Hunag and Liang (2014) find that big five auditors do not constrain EM more than the non-big five auditors. Chunghuey and Hung-Kang (2014) find that big 5 auditors are not more capable than non-big 5 auditors to constrain EM. Garven and Taylor (2015) find a negative relationship between auditors in larger big 4 offices and EM.

The above literature although provides mixed evidence on the association of auditor size with EM, broadly it suggests that the big four auditors are more capable than non-big four auditor in constraining EM. Therefore, the following hypothesis is proposed:

\section{H3: There is a negative relationship between auditor size and EM.}




\section{Data and Research Methodology}

\subsection{Measurement of Variables}

\subsubsection{Dependent Variable - EM}

EM is measured using performance-matched discretionary accruals model proposed by Kothari et al (2005). Discretionary Accruals (DA) estimated using the said model are considered proxy for EM. Since managers can have motivations to do either income increasing EM or income decreasing EM, the study considers the magnitude of EM and not the sign. Therefore, we consider absolute value of DA as the measure for EM. The model is estimated using the following regression for each industry:

$$
T A_{i t} / A_{i t-1}=\alpha_{0}+\alpha_{1 i}\left(1 / A_{i t-1}\right)+\beta_{1 i}\left[\left(\Delta R E V_{i t} / A_{i t-l}\right)-\left(\Delta R E C_{i t} / A_{i t-1}\right)\right]+\beta_{2 i}\left(P P E_{i t} / A_{i t-1}\right)+\beta_{3 i} R O A_{i t-1}+\varepsilon_{i t}
$$

Where $T A_{i t}$ is total accruals for firm $i$ in year $t, A_{i t-1}$ is lagged total assets, $\triangle R E V_{i t}$ is change in revenue in year $t$ for firm $i, \triangle R E C_{i t}$ is change in receivables for firm $i$ in year $t, P P E_{i t}$ is property plant and equipment and $R O A_{i t-1}$ lagged return on assets for firm $i$. Total accruals are computed using the balance sheet approach as the difference between change in non-cash current assets less change in current liabilities (except current portion of long term debt) less depreciation. In the next step, the NDA are computed using the following model:

$$
N D A_{i l} / A_{i t-1}=\alpha_{0}+\alpha_{1 i}\left(1 / A_{i t-1}\right)+\beta_{1 i}\left[\left(\Delta R E V_{i t} / A_{i t-1}\right)-\left(\Delta R E C_{i t} / A_{i t-1}\right)\right]+\beta_{2 i}\left(P P E_{i t} / A_{i t-1}\right)+\beta_{3 i} R O A_{i t-1}
$$

The DA is then the difference between total accruals and NDA. Jones (1991) Model and Modified Jones (1995) model are used for testing the robustness of the results. Under Jones model (1991), the following equation for each industry that has at least 10 firms in year $t$ is estimated:

$$
T A_{i i} / A_{i t-1}=\alpha_{i}\left(1 / A_{i t-1}\right)+\beta_{1 i}\left(\Delta R E V_{i l} / A_{i t-1}\right)+\beta_{2 i}\left(P P E_{i l} / A_{i t-1}\right)+\varepsilon_{i t}
$$

Using the parameters of eq. 3, NDA is calculated using eq.4.

$$
N D A_{i t} / A_{i t-1}=\alpha_{i}\left(1 / A_{i t-1}\right)+\beta_{1 i}\left(\Delta R E V_{i i} / A_{i t-1}\right)+\beta 2 i\left(P P E_{i l} / A_{i t-1}\right)
$$

DA as computed as the difference between TA and NDA. The following equation is used for estimating NDA under Modified Jones (1995) model:

$$
N D A_{i l} / A_{i t-1}=\alpha_{i}\left(1 / A_{i t-1}\right)+\beta_{1 i}\left[\left(\triangle R E V_{i l} / A_{i t-1}\right)-\left(\Delta R E C_{i t} / A_{i t-1}\right)\right]+\beta_{2 i}\left(P P E_{i l} / A_{i t-1}\right)
$$

DA is again computed as the difference between TA and NDA.

\subsubsection{Independent Variables}

Based on the hypotheses presented in the previous chapter, the following independent variables related to corporate governance are used in this study.

i. $\quad$ Non-Audit Fees (NAF): Following previous studies (Frankel et al., 2002; Larcker and Richardson, 2004; Sharma et al. 2011) the NAF is measured by the proportion of non-audit fees paid (taxation matters, and company law and other matters) to the total fees paid to the auditor.

ii. Auditor industry specialization (INDSAUD): We use two alternate measures of INDSAUD:

a. INDSAUD-I: Following Balsam et al. (2003), the first measure is a binary variable which has a value of 1 if the auditor of the firm audits maximum number of firms in the same industry, otherwise 0 .

b. INDSAUD-II: The second measure is also a binary variable which has a value of 1 if the auditor of the firm audits highest proportion of revenue in the same industry, otherwise 0. Following Krishnan (2003) proportion of revenues of industry audited by an auditor is computed using the following formula:

$$
\sum_{i=1}^{n} S i j / \sum_{i=1}^{N} S i
$$

Where, $S_{i j}$ is the revenues of a firm $i$ audited by auditor $j$

$n$ is the number of firms audited by auditor $j$

$N$ is the number of firms in the industry

iii. Auditor size (BIG4): Consistent with the extant literature, auditor size is measured using a binary variable which has a value of 1 if the auditor is a Big 4 auditor, otherwise 0 . 


\subsubsection{Control Variables}

Six variables have been identified from the previous literature, which are known to influence the dependent variable i.e. DA. These variables are:

i. $\quad$ Firm Size (FSIZE): measured by natural log of total assets of the company.

ii. Leverage (LEV): measured by the ratio of total borrowing to total assets.

iii. $\quad$ Firm Performance (PERF): measured using 'return on assets'.

iv. Absolute change in earnings (ABSEC): measured by taking the difference between the EPS of the current period and the previous period.

v. Cash flow from operations (CFO): measured by cash flow from operations scaled by total assets at the beginning of the period.

vi. Prior negative earnings (NEGEARN): measured by a categorical variable that takes the value of 1 if the firm had negative earnings in previous two years; else it takes the value of 0 .

\subsection{Sample and Data}

The study takes a panel data sample of 200 companies listed on Bombay Stock Exchange (BSE) over eight years viz. from financial year 2006-07 to 2013-14. The study considers panel data as it controls for individual heterogeneity, is more informative, and is better to study dynamics of adjustments. Stratified random sampling is used for sampling. Market capitalization and industry classification were used to create strata. This is, perhaps, the first study investigating relationship between auditor's characteristics and EM that takes a stratified random sampling approach for sample selection. The steps followed to select the sample are as below:

i) All listed companies on BSE were taken from Prowess database. There were total 5,496 companies listed on BSE.

ii)From the above, 97 Government owned companies and 1,002 companies belonging to financial sector were eliminated. Government owned companies were eliminated because such companies are not expected to have incentives to manage the earnings. Financial companies were eliminated because these companies have different accrual generation process. These eliminations are in line with previous studies such as Sarkar et al (2008); Jaiswall and Banerjee (2012).

iii) Thereafter, 840 companies which started trading after March 31, 2006 were eliminated as the market capitalization information as on March 31, 2006 was not available.

iv) Then 1,869 firms for which financial data was not available eliminated.

v)Following Sarkar et al. (2008) 106 companies that belonged to industries which had less than 10 companies were eliminated.

vi) After performing the above steps, 1582 companies were left in the population as below:

Table 1. Description of the population

\begin{tabular}{ll}
\hline Particulars & $\begin{array}{l}\text { No. } \\
\text { firms }\end{array}$ \\
\hline All BSE Listed Companies & 5,496 \\
Less: Government Companies & 97 \\
Less: Financial industry companies & 1,002 \\
& $\mathbf{4 , 3 9 7}$ \\
Less: Companies that started trading after Mar 31 2006 & 840 \\
& $\mathbf{3 , 5 5 7}$ \\
Less: Companies for which financial data not available for at least one year & 1,869 \\
Industry less than 10 companies & $\mathbf{1 , 6 8 8}$ \\
Total Population & 106 \\
\hline
\end{tabular}


vii) These 1,582 companies were then classified based on the market capitalization as on March 31, 2006 and the industry classification. The distribution of companies in the population based on market capitalization is as follows:

Table 2. Distribution of companies in population based on size and industry groups

\begin{tabular}{lcccc}
\hline Industry & \multicolumn{4}{c}{ Market Cap } \\
& Large & Mid & Small & Grand Total \\
\hline Accommodation and Food Service Activities & 1 & 4 & 24 & $\mathbf{2 9}$ \\
Administrative and support service activities & - & - & 15 & $\mathbf{1 5}$ \\
Agriculture, forestry and fishing & - & 1 & 14 & $\mathbf{1 5}$ \\
Arts, entertainment and recreation & - & 1 & 12 & $\mathbf{1 3}$ \\
Construction & 2 & 12 & 51 & $\mathbf{6 5}$ \\
Diversified & 2 & 4 & 31 & $\mathbf{3 7}$ \\
Human Health and social work activities & - & 1 & 10 & $\mathbf{1 1}$ \\
Information and Communication & 6 & 9 & 96 & $\mathbf{1 1 1}$ \\
Manufacturing & 31 & 113 & 967 & $\mathbf{1 , 1 1 1}$ \\
Mining and Quarrying & - & - & 13 & $\mathbf{1 3}$ \\
Real Estate Activities & - & 3 & 14 & $\mathbf{1 7}$ \\
Transportation and Storage & - & 3 & 10 & $\mathbf{1 3}$ \\
Wholesale and Retail Trade & 1 & 3 & 128 & $\mathbf{1 3 2}$ \\
Grand Total & $\mathbf{4 3}$ & $\mathbf{1 5 4}$ & $\mathbf{1 , 3 8 6}$ & $\mathbf{1 , 5 8 2}$ \\
\hline
\end{tabular}

viii) In this step, 200 companies were randomly selected, using random numbers, from 39 strata in a manner ensuring balanced stratified random sampling. The distribution of the final sample is given in Table 3.

Table 3. Distribution of companies in sample based on size and industry groups

\begin{tabular}{lllll}
\hline Industry & $\begin{array}{l}\text { Large } \\
\text { Cap }\end{array}$ & $\begin{array}{l}\text { Mid } \\
\text { Cap }\end{array}$ & $\begin{array}{l}\text { Small } \\
\text { Cap }\end{array}$ & Total \\
\hline Accommodation and Food Service Activities & 0 & 1 & 3 & $\mathbf{4}$ \\
Administrative and support service activities & 0 & 0 & 2 & $\mathbf{2}$ \\
Agriculture, forestry and fishing & 0 & 0 & 2 & $\mathbf{2}$ \\
Arts, entertainment and recreation & 0 & 0 & 2 & $\mathbf{2}$ \\
Construction & 0 & 2 & 6 & $\mathbf{8}$ \\
Diversified & 0 & 1 & 4 & $\mathbf{5}$ \\
Human Health and social work activities & 0 & 0 & 1 & $\mathbf{1}$ \\
Information and Communication & 1 & 1 & 12 & $\mathbf{1 4}$ \\
Manufacturing & 5 & 14 & 122 & $\mathbf{1 4 1}$ \\
Mining and Quarrying & 0 & 0 & 2 & $\mathbf{2}$ \\
Real Estate Activities & 0 & 0 & 2 & $\mathbf{2}$ \\
Transportation and Storage & 0 & 0 & 1 & $\mathbf{1}$ \\
Wholesale and Retail Trade & 0 & 0 & 16 & $\mathbf{1 6}$ \\
Total & $\mathbf{6}$ & $\mathbf{1 9}$ & $\mathbf{1 7 5}$ & $\mathbf{2 0 0}$ \\
\hline
\end{tabular}




\subsubsection{Data Collection}

The data has been obtained from the Prowess database maintained by Center for Monitoring Indian Economy (CMIE). This database is widely used for obtaining financial data of Indian companies.

\subsection{Analytical Procedures}

We use following three models to test the hypotheses. The first model (AUD Model 1) considers the first measure of auditor industry specialization (INDSAUD-I), the second model (AUD Model 2) considers the second measure of auditor industry specialization (INDSAUD-II) and the third model (AUD Model 3) utilizes both the measures together.

AUD Model 1:

$A B S D A K=\alpha_{1}+\alpha_{2} N A F+\alpha_{3} I N D S A U D-I+\alpha_{4} B I G 4+\alpha_{5} F S I Z E+\alpha_{6} L E V+\alpha_{7}$ PERF $+\alpha_{8} A B S E C+\alpha_{9} C F O+$ $\alpha_{10} N E G E A R N+\alpha_{11}$ Industry Dummy $+\alpha_{12}$ Year Dummy $+\varepsilon_{i t}$

AUD Model 2:

$A B S D A K=\alpha_{1}+\alpha_{2} N A F+\alpha_{3} I N D S A U D-I I+\alpha_{4} B I G 4+\alpha_{5} F S I Z E+\alpha_{6} L E V+\alpha_{7} P E R F+\alpha_{8} A B S E C+\alpha_{9} C F O+$ $\alpha_{10} N E G E A R N+\alpha_{11}$ Industry Dummy $+\alpha_{12}$ Year Dummy $+\varepsilon_{i t}$

AUD Model 3:

$A B S D A K=\alpha_{1}+\alpha_{2} N A F+\alpha_{3} I N D S A U D-I+\alpha_{4} I N D S A U D-I I+\alpha_{5} B I G 4+\alpha_{6} F S I Z E+\alpha_{7} L E V+\alpha_{8} P E R F+\alpha_{9} A B S E C+$ $\alpha_{10} C F O+\alpha_{11} N E G E A R N+\alpha_{12}$ Industry Dummy $+\alpha_{13}$ Year Dummy $+\varepsilon_{i t}$

The study uses random effect Generalized Least Square (GLS) regression as GLS regression is preferred over OLS regression in case of absent homoscedasticity (Greene, 2003; Berry, 1993; Schroeder et al., 1986). Also GLS overcomes the problem of serial correlation (Berry, 1993; Schroeder et al., 1986). Gujarati and Sangeetha (2007) provide that Hausman (1978) test can be applied to choose between fixed effect model and random effect model. Accordingly, random effect model has been chosen

\section{Results}

\subsection{Descriptive Statistics}

Table 4 presents the descriptive statistics of the variables under the study. The mean of absolute value of DA is 0.1030 with a median at 0.0703 indicating that some companies have relatively high values of DA. The minimum value of absolute DA is close to zero. These values are comparable to the values reported in previous studies on EM in Indian context. Sarkar et al. (2008) report the mean absolute DA of 0.0863. Their sample has total 964 firm-year observations from the years 2003 and 2004. Jaiswall and Banerjee (2012) take a sample of 948 firm-years and report average absolute DA of 0.16. Rajpal (2012) report average absolute DA of 0.097 with a median of 0.0741 from a sample of 572 firm-year observations spanning over three years from 2009 to 2011.

Table 4. Descriptive Statistics

\begin{tabular}{lllllll}
\hline & N & Mean & Median & Minimum & Maximum & $\begin{array}{l}\text { Std. } \\
\text { Deviation }\end{array}$ \\
\hline ABSDAK & 1600 & 0.1030 & 0.0703 & 0.0000 & 0.4809 & 0.1018 \\
NAF & 1600 & 0.2356 & 0.2249 & 0.0000 & 0.6667 & 0.1872 \\
INDSAUD-I & 1600 & 0.1413 & 0.0000 & 0.0000 & 1.0000 & 0.3484 \\
INDSAUD-II & 1600 & 0.0869 & 0.0000 & 0.0000 & 1.0000 & 0.2817 \\
BIG4 & 1600 & 0.2850 & 0.0000 & 0.0000 & 1.0000 & 0.4516 \\
FSIZE & 1600 & 22.2008 & 22.2963 & 17.7275 & 26.3027 & 1.6954 \\
LEV & 1600 & 0.2861 & 0.2564 & 0.0000 & 1.1856 & 0.2423 \\
PERF & 1600 & 5.9721 & 5.2250 & -25.9100 & 32.5500 & 8.8888 \\
ABSEC & 1600 & 8.3971 & 3.1950 & 0.0100 & 83.5400 & 13.8029 \\
CFO & 1600 & 0.0815 & 0.0811 & -0.3855 & 0.4697 & 0.1250 \\
NEGEARN & 1600 & 0.0875 & 0.0000 & 0.0000 & 1.0000 & 0.2827 \\
\hline
\end{tabular}


On average, in the sample companies $23.56 \%$ of the total auditor's remuneration comes from non-audit services. $14.13 \%$ companies in the sample are audited by industry specialized auditor, i.e. by auditors who audits maximum number of companies in the industry. Similarly, $8.69 \%$ of the companies in the sample are audited by auditors who audits maximum amount of revenue in the industry. Big 4 firms and their associates audits $28.50 \%$ of companies under the sample.

\subsection{Econometric Results}

Table 5 presents the results of random effect GLS regression of the three models. The results of the study present a negative relationship between proportion of NAF and the level of EM. In other words, the results suggest that with increase in the proportion of fees from non-audit services, the EM reduces. The results point towards knowledge spillover from non-audit services as argued by Simunic (1984). He argues that providing both auditing as well as management advisory services may give the auditor better understanding of the business model, risk associated etc. of the client and therefore will help in performing the audit function more effectively. The results are also consistent with Beck et al. (1988), for the U.S. companies, and Barkess and Simnett (1994), for Australian companies, who do not find any evidence that non-audit services reduces auditor independence.

Another explanation of a negative relationship between NAF and EM is the reputation concern of the auditor. DeFond et al. (2002) argues that auditors will maintain the independence even if they provide non-audit services due to risk of loss of reputation and litigation costs.

Overall, these results are consistent with Larcker and Richardson (2004), Antle et al. (2006), Krishnan and Visvanathan (2011). Based on the above results, the study accepts the hypothesis (H1) that there is a significant relationship between NAF and EM.

To test the hypothesis on the relationship between auditor industry specialization and EM, this study uses two alternate measures of auditor industry specialization as detailed out earlier. The results suggest that there is no significant relationship between INDSAUD and EM. The results are consistent with Inaam et al. (2012) who document that there is no significant relationship between EM and INDSAUD. Based on the results, the hypothesis (H2) which predicts a negative relationship between INDSAUD and EM is not accepted.

The results of the study suggest that BIG4 is also not related to the level of EM. These results are consistent with Frankel et al. (2002) who find no significant association between auditor size and EM for a sample of 1,537 firm years for the U.S. companies. Similarly, in the context of Australian companies, Davidson et al. (2005) also do not find any significant effect of auditor size on EM. In the context of East Asian companies, Haw et al. (2011) also fails to find any significant association between auditor size and EM. They argue that ineffective role of big 4 auditor in preventing misclassification (proxy for EM) reflects the low litigation risk associated with auditors in East Asian countries, which are generally characterized with poor legal protection. Charfeddine et al. (2013) and Hunag and Liang (2014), in the context of Tunisia and Taiwan respectively, also report insignificant results with respect to the relationship between auditor size and EM. Based on the above results, this study does not accept the hypothesis (H3) that auditor size is negatively related to EM. 
Table 5. Results of Auditor's Model (AUD Model)

\begin{tabular}{|c|c|c|c|c|c|c|c|c|c|c|c|c|}
\hline \multirow[b]{2}{*}{ Variable } & \multicolumn{4}{|c|}{ AUD Model 1} & \multicolumn{4}{|c|}{ AUD Model 2} & \multicolumn{4}{|c|}{ AUD Model 3} \\
\hline & Coeff. & std. error & t-ratio & Sign. & Coeff. & std. error & t-ratio & Sign. & Coeff. & std. error & t-ratio & Sign. \\
\hline Constant & 0.3290 & 0.0484 & 6.7908 & $* * *$ & 0.3273 & 0.0485 & 6.7503 & $* * *$ & 0.3287 & 0.0488 & 6.7415 & $* * *$ \\
\hline NAF & -0.0427 & 0.0156 & -2.7374 & $* * *$ & -0.0430 & 0.0156 & -2.7638 & $* * *$ & -0.0427 & 0.0156 & -2.7377 & $* * *$ \\
\hline INDSAUD-I & -0.0032 & 0.0104 & -0.3069 & & & & & & -0.0031 & 0.0104 & -0.3013 & \\
\hline INDSAUD-II & & & & & -0.0012 & 0.0122 & -0.0972 & & -0.0009 & 0.0123 & -0.0725 & \\
\hline BIG4 & 0.0021 & 0.0089 & 0.2378 & & 0.0011 & 0.0084 & 0.1306 & & 0.0023 & 0.0093 & 0.2500 & \\
\hline FSIZE & -0.0083 & 0.0023 & -3.6182 & $* * *$ & -0.0082 & 0.0023 & -3.5705 & $* * *$ & -0.0083 & 0.0023 & -3.5781 & $* * *$ \\
\hline LEV & -0.0072 & 0.0160 & -0.4492 & & -0.0071 & 0.0160 & -0.4419 & & -0.0073 & 0.0161 & -0.4533 & \\
\hline PERF & 0.0011 & 0.0004 & 2.8196 & $* * *$ & 0.0011 & 0.0004 & 2.8202 & $* * *$ & 0.0011 & 0.0004 & 2.8176 & $* * *$ \\
\hline $\mathrm{CFO}$ & -0.0672 & 0.0224 & -2.9983 & $* * *$ & -0.0674 & 0.0224 & -3.0108 & $* * *$ & -0.0671 & 0.0224 & -2.9951 & $* * *$ \\
\hline NEGEARN & 0.0019 & 0.0104 & 0.1831 & & 0.0021 & 0.0104 & 0.1992 & & 0.0019 & 0.0104 & 0.1846 & \\
\hline Industry Fixed Effects & Included & & & & Included & & & & Included & & & \\
\hline \multirow[t]{3}{*}{ Year Fixed Effects } & Included & & & & Included & & & & Included & & & \\
\hline & Test & & & & Test & & & & Test & & & \\
\hline & Statistic & p-value & Sign. & & Statistic & p-value & Sign. & & Statistic & p-value & Sign. & \\
\hline Wald Test (Chi-square) & 108.4260 & 0.0000 & $* * *$ & & 108.3070 & 0.0000 & $* * *$ & & 108.2420 & 0.0000 & $* * *$ & \\
\hline Breusch-Pagan test & 68.9618 & 0.0000 & $* * *$ & & 68.9296 & 0.0000 & $* * *$ & & 68.7471 & 0.0000 & $* * *$ & \\
\hline Hausman test & 10.5373 & 0.83711 & & & 9.9314 & 0.870185 & & & 11.0666 & 0.853079 & & \\
\hline
\end{tabular}

This section presents and discusses number of robustness tests of the results and further analysis of the relationship between corporate governance and EM.

\subsubsection{Alternate Specification of EM}

Alternate measures of EM estimated by Jones (1991) model and Modified Jones (1995) model are used for testing the robustness of the results. The dependent variables, alternately, are ABSDAJ using Jones (1991) model and ABSDAMJ using Modified Jones (1995) model. Table 6 presents the results.

The results on the relationship between NAF and EM remain consistent under alternate specifications of EM, suggesting that higher level of NAF is associated with lower level of EM. This provides further evidence to the 'knowledge-spillover' hypothesis. The coefficients of other characteristics viz. INDSAUD-I, INDSAUD-II and BIG4 remain insignificant. The above findings suggest that the results of this study are robust to different specifications of DA.

\subsubsection{Working Capital Accruals}

This study has used DA to proxy for EM. Total accruals (i.e. after considering the effect of depreciation) are considered for this purpose. However, it has been argued that working capital accruals tend to be more opaque than the total accruals because they include judgmental items such as provision for doubtful debts, warranties etc. (Peasnell et al., 2000). Depreciation, they argue, has limited potential to be managed because of its visibility. They also argue that "working capital accrual management is not directly observable." For testing the robustness of the previous results, this study also test the relationship of corporate governance variables with discretionary working capital accruals (ABSDWCAK). For this purpose, following Peasnell et al. (2000) firstly the working capital accruals are computed using the below equation:

$$
W C A_{i t}=\Delta C A_{i t}-\triangle C L_{i t}-\triangle C a s h_{i t}+\triangle S T D_{i t}
$$


Where, $\mathrm{WCA}_{\mathrm{it}}=$ working capital accruals in period $t$ for firm $i$

$\Delta \mathrm{CA}_{\mathrm{it}}=$ Change in current assets in period $t$ from period $t-1$

$\Delta \mathrm{CL}_{\mathrm{it}}=$ Change in current liabilities in period $t$ from period $t-1$

$\Delta \mathrm{Cash}_{\mathrm{it}}=$ Change in cash and cash equivalents in period $t$ from period $t-1$

$\Delta$ STDit $=$ Change in short term debt in period $t$ from period $t-1$

In the next step, using equation 10 the working capital accruals are regressed using Kothari et al. (2005) model.

$$
W C A_{i t} / A_{i t-1}=\alpha_{i}\left(1 / A_{i t-1}\right)+\beta_{1 i}\left[\left(\Delta R E V_{i t} / A_{i t-1}\right)-\left(\Delta R E C_{i t} / A_{i t-1}\right)\right]+\beta_{2 i}\left(P P E_{i t} / A_{i t-1}\right)+\beta_{3 i} R O A_{i t-1}+\varepsilon_{i t}
$$

Where, $\mathrm{WCA}_{\mathrm{it}}=$ Working capital accrual for company i period $\mathrm{t}$

In the third step, the non-discretionary working capital accruals are estimated using the coefficients of equation 10 above. The following equation is used to estimate non-discretionary working capital accruals:

$$
N D W C A_{i t} / A_{i t-1}=\alpha_{i}\left(1 / A_{i t-1}\right)+\beta_{1 i}\left[\left(\Delta R E V_{i t} / A_{i t-1}\right)-\left(\Delta R E C_{i t} / A_{i t-1}\right)\right]+\beta_{2 i}\left(P P E_{i t} / A_{i t-1}\right)+\beta_{3 i} R O A_{i t-I}+\varepsilon_{i t}
$$

The last step is to estimate the discretionary portion of the working capital accruals, which is computed as below:

$$
D W C A K_{i t}=W C A_{i t}-N D W C A_{i t}
$$

Like previously, the study considers the absolute value of the discretionary working capital accruals. Hence, the dependent variable is the absolute value of discretionary working capital accruals (ABSDWCAK). The results are presented in Table 7.

Table 6. Alternative specification of EM

\begin{tabular}{lllllll}
\hline & ABSDAJ & & \multicolumn{3}{c}{ ABSDAMJ } & \\
Variable & Coeff. & t-ratio & Sign. & Coeff. & t-ratio & Sign. \\
\hline constant & 0.3206 & 7.6108 & $* * *$ & 0.3336 & 7.6703 & $* * *$ \\
NAF & -0.0450 & -2.7889 & $* * *$ & -0.0403 & -2.3926 & $* *$ \\
INDSAUD-I & 0.0017 & 0.1442 & & -0.0018 & -0.1501 & \\
INDSAUD-II & -0.0042 & -0.3646 & & -0.0052 & -0.4269 & \\
BIG4 & -0.0023 & -0.2627 & & -0.0018 & -0.1941 & \\
FSIZE & -0.0086 & -4.0639 & $* * *$ & -0.0086 & -3.9592 & $* * *$ \\
LEV & 0.0044 & 0.2682 & & -0.0013 & -0.0777 & \\
PERF & 0.0015 & 2.947 & $* * *$ & 0.0014 & 2.5750 & $* *$ \\
ABSEC & 0.0002 & 0.9862 & & 0.0003 & 1.0639 & \\
CFO & -0.0716 & -2.0393 & $* *$ & -0.0873 & -2.4996 & $* *$ \\
NEGEARN & 0.0100 & 0.9025 & & 0.0129 & 1.0507 & \\
Industry Fixed Effects & Included & & & Included & & \\
Year Fixed Effects & Included & & & Included & & \\
& & & & Test & & \\
& Test Statistic & p-value & Sign. & Statistic & p-value & Sign. \\
Wald Test (Chi-square) & 23.745 & 0.0013 & $* * *$ & 25.281 & 0.0007 & $* * *$ \\
Breusch-Pagan test & 57.158 & 0.0000 & $* * *$ & 51.763 & 0.0000 & $* * *$ \\
Hausman test & 10.761 & 0.3765 & & 12.130 & 0.2764 & \\
Adj. R-Square & $6.10 \%$ & & & $6.26 \%$ & & \\
\hline
\end{tabular}


Table 7. AUD Model using working capital accruals

\begin{tabular}{lllll}
\hline Variable & Coeff. & std. error & t-ratio & Sign. \\
\hline constant & 0.3254 & 0.0433 & 7.5122 & $* * *$ \\
NAF & -0.0432 & 0.0163 & -2.6512 & $* * *$ \\
INDSAUD-I & -0.0028 & 0.0113 & -0.2506 & \\
INDSAUD-II & -0.0001 & 0.012 & -0.0109 & \\
BIG4 & 0.0014 & 0.0088 & 0.1601 & \\
FSIZE & -0.0081 & 0.002 & -3.9056 & $* * *$ \\
LEV & -0.012 & 0.0155 & -0.7742 & \\
PERF & 0.0009 & 0.0005 & 1.7346 & $*$ \\
ABSEC & 0.0004 & 0.0002 & 2.025 & $* *$ \\
CFO & -0.0732 & 0.0343 & -2.1367 & $* *$ \\
NEGEARN & -0.0001 & 0.0095 & -0.0173 & \\
Industry Fixed Effects & Included & & & \\
Year Fixed Effects & Included & & & \\
& Test & & & \\
Wald Test (Chi-square) & 28.614 & 0.000 & $* * *$ & \\
Breusch-Pagan test & 77.7216 & 0.000 & $* * *$ & \\
Hausman test & 11.8155 & 0.2976 & & \\
Adj. R-Square & $7.152 \%$ & & & \\
\hline
\end{tabular}

'***', '**', and '*' denote significance at $1 \%, 5 \%$ and $10 \%$ respectively.

\subsubsection{Change in NAF}

A sharp growth in NAF may increase auditor's economic dependence on a client thereby compromising the independence of the auditor (Cahan et al., 2008). Therefore, this study examines the effect of the change in the ratio of NAF to total fee from previous period to current period on EM. For this purpose, the model is analyzed by replacing the variable 'NAF' with change in the non-audit fee ratio (CHNAF). The results are presented in table 8.

We find a negative and significant relationship between change in CHNAF and EM. This provides further evidence of the 'knowledge spillover' hypothesis which suggests that non-audit services provides better understanding of the business model, risk associated etc. of the client and therefore will help in performing the audit function more effectively. All other relationships are similar to earlier results. 
Table 8. Effect of Change in non-audit fees

\begin{tabular}{|c|c|c|c|c|}
\hline Variable & Coeff. & std. error & t-ratio & Sign. \\
\hline constant & 0.3275 & 0.0523 & 6.2616 & $* * *$ \\
\hline CHNAF & -0.0453 & 0.0183 & -2.4763 & $* *$ \\
\hline INDSAUD-I & 0.0027 & 0.0109 & 0.2553 & \\
\hline INDSAUD-II & -0.0002 & 0.0132 & -0.0175 & \\
\hline BIG4 & -0.003 & 0.0095 & -0.3235 & \\
\hline FSIZE & -0.0092 & 0.0023 & -3.8835 & $* * *$ \\
\hline $\mathrm{LEV}$ & -0.0013 & 0.017 & -0.0811 & \\
\hline PERF & 0.0012 & 0.0004 & 2.9995 & $* * *$ \\
\hline ABSEC & 0.0006 & 0.0002 & 3.017 & $* * *$ \\
\hline $\mathrm{CFO}$ & -0.0337 & 0.0243 & -1.3897 & \\
\hline NEGEARN & 0.0026 & 0.0108 & 0.2404 & \\
\hline Industry Fixed Effects & Included & & & \\
\hline Year Fixed Effects & Included & & & \\
\hline & $\begin{array}{l}\text { Test } \\
\text { Statistic }\end{array}$ & p-value & Sign. & \\
\hline Wald Test (Chi-square) & 114.853 & 0.000 & $* * *$ & \\
\hline Breusch-Pagan test & 55.6123 & 0.000 & $* * *$ & \\
\hline Hausman test & 10.2263 & .421 & & \\
\hline Adj. R-Square & $8.488 \%$ & & & \\
\hline
\end{tabular}

\section{Conclusion}

This study examines the effect of auditor's characteristics on EM in India. Using prior literature, the study identified three major factors related to auditor's that may influence the level of EM. Firstly, the fees received for non-audit services may reflect the level of economic dependence of auditor on the client and therefore, may influence his independence of opinion. On the other hand, more services may equip the auditor to better understand the business and operational risk and help in effectively executing the auditing responsibility. Secondly, if the auditor specializes in a particular industry, he may be able to better audit the client from the same industry. Hence, the industry specialization of auditor may influence his ability to detect EM. Lastly, the size of auditor may affect the ability to detect EM. A large auditor may be equipped with better resources to detect EM or may be more vigilant due to reputation effect. A small auditor, on the other hand, may have better understanding of local business practices and therefore, may be more effective in constraining EM.

The study takes a panel data sample of 200 companies spread over eight years and measures EM using performance matched discretionary accruals model proposed by Kothari et al. (2005). The study finds that there is a negative relationship between EM and NAF. The negative relationship points towards the knowledge spillover effect of auditor. The results, therefore, suggest that the with more non-audit services provided by the auditor, the level of EM reduces. The study does not find any significant relationship between INDSAUD and EM, and BIG4 and EM.

This study is, perhaps, the first study which examines the relationship of EM with auditor's characteristics in Indian context. This study will be helpful to the regulators and auditing standard setting boards to improve on the auditing standards and practices. The study can also help investors or potential investors understand the efficacy of audit conducted for the firm. Lastly, this study adds to the existing literature on EM and measures to constrain the practices of EM.

\section{References}

Abdullahi, L. B., \& Ibrahim, S. O. (2017). An Evaluation of Factors Determining Earnings Management in Nigeria. Amity Global Business Review, 12, 33-45. 
Ajina, A., Bouchareb, M., \& Souid, S. (2013). Corporate governance mechanisms and earnings management after and before the adoption of IFRS. The Business \& Management Review, 3(4), 147.

Ali, A., \& Pope, P. F. (1995). THE INCREMENTAL INFORMATION CONTENT OF EARNINGS, FUNDS FLOW AND CASH FLOW: THE UK EVIDENCE. Journal of Business Finance \& Accounting, 22(1), 19-34. https://doi.org/10.1111/j.1468-5957.1995.tb00669.x

Antle, R., Gordon, E., Narayanamoorthy, G., \& Zhou, L. (2006). The joint determination of audit fees, non-audit fees, and abnormal accruals. Review of Quantitative Finance and Accounting, 27(3), 235-266. https://doi.org/10.1007/s11156-006-9430-y

Ashbaugh, H., LaFond, R., \& Mayhew, B. W. (2003). Do Nonaudit Services Compromise Auditor Independence? Further Evidence. The Accounting Review, 78(3), 611-639. https://doi.org/10.2308/accr.2003.78.3.611

Balsam, S., Krishnan, J., \& Yang, J. S. (2003). Auditor Industry Specialization and Earnings Quality. AUDITING: A Journal of Practice \& Theory, 22(2), 71-97. https://doi.org/10.2308/aud.2003.22.2.71

Barkess, L., \& Simnett, R. (1994). The Provision of Other Services by Auditors: Independence and Pricing Issues. Accounting and Business Research, 24(94), 99-108. https://doi.org/10.1080/00014788.1994.9729469

Beck, P. J., Frecka, T. J., \& Solomon, I. (1988). A model of the market for MAS and audit services: Knowledge spillovers and auditor-auditee bonding. Journal of Accounting Literature, 7(1), 50-64.

BECKER, C. L., DEFOND, M. L., JIAMBALVO, J., \& SUBRAMANYAM, K. R. (1998). The Effect of Audit Quality on Earnings Management. Contemporary Accounting Research, 15(1), 1-24. https://doi.org/10.1111/j.1911-3846.1998.tb00547.x

Beeler, J. D., \& Hunton, J. E. (n.d.). Contingent economic rents: Insidious threats to audit independence (pp. 21-50). https://doi.org/10.1016/S1474-7979(02)05036-6

Berry, W. (1993). Understanding Regression Assumptions. 2455 Teller Road, Thousand Oaks California 91320 United States of America: SAGE Publications, Inc. https://doi.org/10.4135/9781412986427

Burnett, B. M., Cripe, B. M., Martin, G. W., \& McAllister, B. P. (2012). Audit Quality and the Trade-Off between Accretive Stock Repurchases and Accrual-Based Earnings Management. The Accounting Review, 87(6), 1861-1884. https://doi.org/10.2308/accr-50230

Cahan, S., Emanuel, D., Hay, D., \& Wong, N. (2008). Non-audit fees, long-term auditor-client relationships and earnings management. Accounting \& Finance, 48(2), 181-207. https://doi.org/10.1111/j.1467-629X.2008.00251.x

Carcello, J. V., \& Nagy, A. L. (2004). Client size, auditor specialization and fraudulent financial reporting. Managerial Auditing Journal, 19(5), 651-668. https://doi.org/10.1108/02686900410537775

Charfeddine, L., Riahi, R., \& Omri, A. (2013). The determinants of earnings management in developing countries: A study in the Tunisian context. IUP Journal of Corporate Governance, 12(1), 35.

Chen, H., Chen, J. Z., Lobo, G. J., \& Wang, Y. (2011). Effects of Audit Quality on Earnings Management and Cost of Equity Capital: Evidence from China*. Contemporary Accounting Research, 28(3), 892-925. https://doi.org/10.1111/j.1911-3846.2011.01088.x

Chi, W., Lisic, L. L., \& Pevzner, M. (2011). Is Enhanced Audit Quality Associated with Greater Real Earnings Management? Accounting Horizons, 25(2), 315-335. https://doi.org/10.2308/acch-10025

Chung, H., \& Kallapur, S. (2003). Client Importance, Nonaudit Services, and Abnormal Accruals. The Accounting Review, 78(4), 931-955. https://doi.org/10.2308/accr.2003.78.4.931

Chunghuey, H., \& Hung-Kang, L. (2014). Can Auditors Restrain Firms from Earnings Management? International Journal of Business \& Information, 9(3), 361-387.

DAS, S., \& LEV, B. (1994). Nonlinearity in the Returns-Earnings Relation: Tests of Alternative Specifications and Explanations. Contemporary Accounting Research, $11(1), \quad 353-379$. https://doi.org/10.1111/j.1911-3846.1994.tb00447.x

Davidson, R., Goodwin-Stewart, J., \& Kent, P. (2005). Internal governance structures and earnings management. Accounting and Finance, 45(2), 241-267. https://doi.org/10.1111/j.1467-629x.2004.00132.x 
DeAngelo, L. E. (1981). Auditor size and audit quality. Journal of Accounting and Economics, 3(3), 183-199. https://doi.org/10.1016/0165-4101 (81)90002-1

Dechow, P. M., Sloan, R. G., \& Sweeney, A. P. (1995). Detecting earnings management. Accounting review, 193-225.

DECHOW, P. M., SLOAN, R. G., \& SWEENEY, A. P. (1996). Causes and Consequences of Earnings Manipulation: An Analysis of Firms Subject to Enforcement Actions by the SEC. Contemporary Accounting Research, 13(1), 1-36. https://doi.org/10.1111/j.1911-3846.1996.tb00489.x

DeFond, M. L., Raghunandan, K., \& Subramanyam, K. R. (2002). Do Non-Audit Service Fees Impair Auditor Independence? Evidence from Going Concern Audit Opinions. Journal of Accounting Research, 40(4), 1247-1274. https://doi.org/10.1111/1475-679X.00088

Dopuch, N., \& Simunic, D. (1980). The nature of competition in the auditing profession: a descriptive and normative view. Regulation and the accounting profession, 34(2), 283-289.

Easton, P. D., Harris, T. S., \& Ohlson, J. A. (1992). Aggregate accounting earnings can explain most of security returns: The case of long return intervals. Journal of Accounting and Economics, 15(2-3), 119-142. https://doi.org/10.1016/0165-4101(92)90015-T

Fama, E. F., \& Jensen, M. C. (1983). Separation of Ownership and Control. The Journal of Law and Economics, 26(2), 301-325. https://doi.org/10.1086/467037

Frankel, R. M., Johnson, M. F., \& Nelson, K. K. (2002). The Relation Between Auditor's Fees for Non-audit Services and Earnings Quality (No. 1696r).

Garven, S., \& Taylor, G. (2015). BIG 4 AUDITOR OFFICE SIZE, ANALYSTS' ANNUAL EARNINGS FORECASTS AND CLIENT EARNINGS MANAGEMENT BEHAVIOR. Academy Of Accounting \& Financial Studies Journal, 19(3), 103-124.

Ghosh, S. (2011). Firm ownership type, earnings management and auditor relationships: evidence from India. Managerial Auditing Journal, 26(4), 350-369. https://doi.org/10.1108/02686901111124666

Gore, J. P. O., Pope, P. F., \& Singh, A. (2001). Non-audit services, auditor independence and earnings management. Lancaster University Working paper 2001/014. Retrieved from http://www.lums.co.uk/publications.

Greene, W. H. (2003). Econometric analysis. Pearson Education India.

Gujarati, D. N., \& Sangeetha (2009). Basic econometrics. Tata McGraw-Hill Education.

Hausman, J. A. (1978). Specification Tests in Econometrics. Econometrica, 46(6), 1251. https://doi.org/10.2307/1913827

Haw, I.-M., Ho, S. S. M., \& Li, A. Y. (2011). Corporate Governance and Earnings Management by Classification Shifting*. Contemporary Accounting Research, 28(2), 517-553. https://doi.org/10.1111/j.1911-3846.2010.01059.x

Huang, C., \& Liang, H. K. (2014). Can Auditors Restrain Firms from Earnings Management? International Journal of Business and Information, 9(3), 361.

Huang, S. L. C. L. H., \& Hsiao, H. C. (2011). Study of earnings management and audit quality. African Journal of Business Management, 5(7), 2686.

Inaam, Z., Khmoussi, H., \& Fatma, Z. (2012). Audit Quality and Earnings Management in the Tunisian Context. International Journal of Accounting and Financial Reporting, 2(2), 17. https://doi.org/10.5296/ijafr.v2i2.2065

India. Central Statistical Organization, Ministry of Statistics and Programme Implementation, Government of India. New Delhi. National Industrial Classification. N.p.: n.p., 2008. Web. <www.mospi.nic.in>.

The Institute of Chartered Accountants of India. New Delhi. Guidance Note on Independence of Auditors. January 2005 ed. Print.

Jaiswall, M., \& Banerjee, A. (2012). Are Family firms in India managing their Earnings-An exploratory study. Indian Institute of Management Calcutta Working Paper Series, WPS No.703/ July 2012

Jones, J. J. (1991). Earnings Management During Import Relief Investigations. Journal of Accounting Research, 29(2), 193. https://doi.org/10.2307/2491047 
Jordan, C. E., Clark, S. J., \& Hames, C. C. (2010). The Impact Of Audit Quality On Earnings Management To Achieve User Reference Points In EPS. Journal of Applied Business Research (JABR), 26(1). https://doi.org/10.19030/jabr.v26i1.273

Kallunki, J.-P., \& Martikainen, T. (1997). The lead-lag structure of stock returns and accounting earnings: Implications to the returns-earnings relation in Finland. International Review of Financial Analysis, 6(1), 37-47. https://doi.org/10.1016/S1057-5219 (97)90018-1

Kothari, S. P., Leone, A. J., \& Wasley, C. E. (2005). Performance matched discretionary accrual measures. Journal of Accounting and Economics, 39(1), 163-197. https://doi.org/10.1016/j.jacceco.2004.11.002

Krishnan, G. V. (2003). Does Big 6 Auditor Industry Expertise Constrain Earnings Management? Accounting Horizons, 17(s-1), 1-16. https://doi.org/10.2308/acch.2003.17.s-1.1

Krishnan, G. V., \& Visvanathan, G. (2011). Is There an Association between Earnings Management and Auditor-Provided Tax Services? The Journal of the American Taxation Association, 33(2), 111-135. https://doi.org/10.2308/atax-10055

Larcker, D. F., \& Richardson, S. A. (2004). Fees Paid to Audit Firms, Accrual Choices, and Corporate Governance. Journal of Accounting Research, 42(3), 625-658. https://doi.org/10.1111/j.1475-679X.2004.t01-1-00143.x

LIM, C.-Y., \& TAN, H.-T. (2008). Non-audit Service Fees and Audit Quality: The Impact of Auditor Specialization. Journal of Accounting Research, 46(1), 199-246. https://doi.org/10.1111/j.1475-679X.2007.00266.x

Liu, J., \& Thomas, J. (2000). Stock Returns and Accounting Earnings. Journal of Accounting Research, 38(1), 71. https://doi.org/10.2307/2672923

Lisic, L. L. (2014). Auditor-Provided Tax Services and Earnings Management in Tax Expense: The Importance of Audit Committees. Journal of Accounting, Auditing \& Finance, 29(3), 340-366. doi:10.1177/0148558X14536046

Louis, H. (2005). Acquirers' abnormal returns and the non-Big 4 auditor clientele effect. Journal of Accounting and Economics, 40(1), 75-99. https://doi.org/10.1016/j.jacceco.2005.03.001

Memis, M. U., \& Cetenak, E. H. (2012). Earnings management, audit quality and legal environment: An international comparison. International Journal of Economics and Financial Issues, 2(4), 460.

Owhoso, V. E., Messier, Jr., W. F., \& Lynch, Jr., J. G. (2002). Error Detection by Industry-Specialized Teams during Sequential Audit Review. Journal of Accounting Research, 40(3), 883-900. https://doi.org/10.1111/1475-679X.00075

Palmrose, Z.-V. (1986). The Effect of Nonaudit Services on the Pricing of Audit Services: Further Evidence. Journal of Accounting Research, 24(2), 405. https://doi.org/10.2307/2491144

Palmrose, Z. V. (1988). 1987 Competitive Manuscript Co-Winner: An analysis of auditor litigation and audit service quality. Accounting review, 55-73.

PEASNELL, K. V., POPE, P. F., \& YOUNG, S. (2000). ACCRUAL MANAGEMENT TO MEET EARNINGS TARGETS: UK EVIDENCE PRE- AND POST-CADBURY. The British Accounting Review, 32(4), 415-445. https://doi.org/10.1006/bare.2000.0134

Rajpal, H. (2012). Independent Directors and Earnings Management: Evidence from India. International Journal of Accounting and Financial Management Research. ISSN, 2249-6882.

Rusmin, R. (2010). Auditor quality and earnings management: Singaporean evidence. Managerial Auditing Journal, 25(7), 618-638. https://doi.org/10.1108/02686901011061324

Sarkar, J., Sarkar, S., \& Sen, K. (2008). Board of Directors and Opportunistic Earnings Management: Evidence from India. Journal of Accounting, Auditing \& Finance, 23(4), 517-551. https://doi.org/10.1177/0148558X0802300405

Schroeder, L., Sjoquist, D., \& Stephan, P. (1986). Understanding Regression Analysis. 2455 Teller Road, Newbury Park California 91320 United States of America: SAGE Publications, Inc. https://doi.org/10.4135/9781412986410

Sharma, V. D., Sharma, D. S., \& Ananthanarayanan, U. (2011). Client Importance and Earnings Management: The Moderating Role of Audit Committees. AUDITING: A Journal of Practice \& Theory, 30(3), 125-156. https://doi.org/10.2308/ajpt-10111 
Simunic, D. A. (1984). Auditing, Consulting, and Auditor Independence. Journal of Accounting Research, 22(2), 679. https://doi.org/10.2307/2490671

Solomon, I., Shields, M. D., \& Whittington, O. R. (1999). What Do Industry-Specialist Auditors Know? Journal of Accounting Research, 37(1), 191. https://doi.org/10.2307/2491403

Sun, J., \& Liu, G. (2012). Auditor industry specialization, board governance, and earnings management. Managerial Auditing Journal, 28(1), 45-64. https://doi.org/10.1108/02686901311282498

Taxmann Allied Services (2014). A Comparative Study of Companies Act 2013 with Rules \& Companies Act 1956 with Rules. New Delhi: Taxmann Allied Services

Tepalagul, N., \& Lin, L. (2015). Auditor independence and audit quality: A literature review. Journal of Accounting, Auditing \& Finance, 30(1), 101-121. https://doi.org/10.1177/0148558X14544505

Wang, Z., Swift, K., \& Lobo, G. (1993). Earnings management and the informativeness of accruals adjustments. Working Paper, Montana State University.

WILliAMSON, O. E. (1988). Corporate Finance and Corporate Governance. The Journal of Finance, 43(3), 567-591. https://doi.org/10.1111/j.1540-6261.1988.tb04592.x 